\title{
Rethinking sustainability: a review of Liberia's municipal solid waste management systems, status, and challenges
}

\author{
Victor Emery David Jr ${ }^{1}\left[\right.$. Yasinta John ${ }^{1}$. Shahid Hussain ${ }^{2}$
}

Received: 18 October 2019 / Accepted: 21 April 2020 / Published online: 6 May 2020

(c) Springer Japan KK, part of Springer Nature 2020

\begin{abstract}
The appalling state of Liberia's municipal solid waste management system (MSWM) is the motivation for this review and analysis. Solid waste management protocols and system dynamic modeling support policy development as it uses waste prevention to explain the complex waste management systems and suggests methods for effective management. However, creating an effective waste system goes beyond the formulation of policies and legislation; it involves financial and technological proficiency, skilled human capacity, technical, social, resource recycling, educational awareness programs, and active public participation. Because of urbanization, Liberia's municipal solid waste (MSW) problems have become heightened, thereby impacting the economic, social, and political fabric of society by overburdening infrastructure and social facilities. The impact of urbanization must be addressed because urbanization, amongst several factors, including unsustainable management of MSW, degrades the environment and presents risks to public health. The purpose of this review was to highlight the current waste management activities in Liberia and provide information to the readers about the challenges facing the waste management sector and the challenges impeding the development of a sustainable waste management system. In Liberia, waste management activities are getting worse daily due to shortage of a comprehensive waste management framework, the absence of guidelines regarding the responsibilities of waste generators, and the decision-makers' lack of intent to design and implement a sustainable and integrated management system. Recommendations for collaborative efforts are made by focusing on delivering a waste strategy which concentrates on waste minimization, recycling, resource recovery, and promoting sustainable waste management practices for communities, small businesses, corporations, and government institutions in Liberia and other developing countries.
\end{abstract}

Keywords Municipal solid waste (MSW) · Urbanization · Recycling $\cdot$ Indiscriminate dumping $\cdot$ Regulatory frameworks Liberia

\section{Introduction}

Liberia had its first democratic transfer of power in over 70 years [1], following the election of George Weah as president in December 2017. Weah government's pro-poor agenda for prosperity and development has sought to stimulate economic growth, but the challenges of widespread abject poverty and high inflation have made economic

Victor Emery David Jr

emerydavid2011@gmail.com

$1 \quad$ Faculty of Urban Construction and Environmental Engineering, Chongqing University, Chongqing 400045, People's Republic of China

2 School of Materials Science and Engineering, Jiangsu University, Zhenjiang 212013, China growth a challenging task. The effect of urbanization has been seen in different urban cities across the country since the early 1990s [2, 3]. Around 50.7 percent of the population of Liberia now lives in metropolitan areas which have contributed to the increased generation of waste, typical for most developing countries [4, 5]. Furthermore, the effect of urbanization is a major contributing factor to the increasingly poor environmental conditions in various urban centers in Liberia [6]. Liberia is divided into 15 counties: Montserrado, Nimba, Bong, Lofa, and Grand Bassa counties are highly populated with more than 3 million inhabitants combined, while Bomi, Gbarpolu, Rivercess, Rivergee, and Grand Kru are the least populated, having a population of 100,000 or more. Grand Kru is the least with a population of 57,913 [2, 7]. The effects of urbanization on these geographical divisions include environmental degradation, 
pollution, and waste disposal problems. Liberia, like many countries in the world, is faced with the challenge of increased waste generation. Waste is generated daily due to numerous factors ranging from affluence, rapid economic growth, rapid urbanization, changes in consumption patterns, rapid population growth, etc.[8]. Similarly, generated waste is improperly managed in most developing countries [8]. This inadequate management of waste poses serious risks to the environment and public health [7, 9]. The Liberian Government has taken steps to manage solid waste to some extent. Between 2015 and 2018, the World Bank and the European Union financially supported three major solid waste projects [6]. The Cheesemanburg Landfill Urban Sanitation (CLUS), the Emergency Monrovia Urban Sanitation Project (EMUS), and EU Water Facility Project, funded by the World Bank and the European Union were primarily focused on providing support for the key and minor waste assortment and enhancing disposal and sanitation in Monrovia. Additionally, infrastructure for solid waste was set up at two transfer stations (Stockton Creek and Fiamah), three installed weighbridges (landfill and transfer stations), 120 communal disposal locations throughout the Greater Monrovia area, and a sanitary Whein Town landfill. The EMUS Project closed in December 2016, while the EU Water Facility Project ended 2017 due to the Ebola outbreak. The Cheesemanburg Landfill Urban Sanitation (CLUS) project which is aimed at improving access to solid waste collection and disposal in Monrovia and other parts of the country is currently ongoing and is expected to replace the Whein Town facility in 2 years. While progress has been made to manage waste, sustainable solid waste management in the country still remains a challenge. Unsustainable solid waste management poses high risks to public health in many least developed countries in Africa [10,11] due to high population growth and increasing waste generation patterns. The effects of unsustainable solid waste management practices include land degradation, breeding sites for mosquitoes and other vectors, diseases, impact on land valuation, and illnesses [12]. These examples show why it is imperative for policymakers to prioritize sustainable waste management. Recent research has shown that approximately 2.2 billion people have inadequate access to basic sanitation services [13, 14]. Against this background, governments around the world have become increasingly interested in sustainable environment thus contributing to the formulation of several approaches to minimizing waste, enhancing waste recovery, promoting waste recycling $[14,15]$, and safe landfill waste disposal [16]. Additionally, most developed countries have prioritized waste management activities followed by the complete adoption of the 4Rs; 'reduction, reclaiming, recycle and reusing or recovery' of scrap. Similarly, the adoption of the waste-to-energy ( $\mathrm{WtE}$ ) approach has also been implemented by developed and some developing countries including China, South Africa, Australia, and The Netherlands [11]. Waste-to-energy involves the cycle of treatment that produces energy in the form of power, the production of clean, renewable energy, and resource recovery from the sustainable management of MSW [17, 18]. Studies have also indicated that zero waste catalyzes sustainable manufacture and use, optimizes reutilizing and the reuse of resource, and minimizes incineration and landfilling [14, 17, 18]. Therefore, the utilization of solid waste is environmentally, socially, and economically viable. It is essential that developing countries, including Liberia, incorporate these approaches in order to sustainably manage waste, thus minimizing pollution to the environment [18-21].

Liberia has a tropical climate that involves two seasons: wet season (rainy) and dry season. Each season provides different patterns of consumption and waste generation. Yet, since the first State of the Environment report, [12] no further reports have been produced by the government nor steps taken to analyze environmental impact or waste generation patterns. However, a recent study conducted by Victor E. David Jr et al. [15] highlighted the linkage between population and development and the increase in waste generation in the country. In addition, data for research and policy purposes are generally limited due to the lack of research and development [22]. In a study conducted by the Emergency Monrovia Urban Sanitation project [EMUS, [17], in collaboration with the municipal corporation in Monrovia, the annual tons of inert waste generated in the provincial capital city of Monrovia was reported as 780 tons /day with an average waste generation of $0.63 \mathrm{~kg} /$ capita a day in 2017 [16, 23]. Additionally, data regarding waste generated in other parts of the country are still unavailable. Liberia, a signatory to major environmental conventions, is still lacking because of the gap between the ratification of these conventions and implementation. Also, the lack of knowledge regarding the implementation of integrated programs; inadequately skilled individuals; the lack of financial, technical, strategic and technological resources; inconsistent guidelines regarding waste management; lack of institutionalizing the informal reprocessing industry; minimal research and development activities; the absence of engineered sanitary landfills; the absence of opportunities for recycling and the lack of developed infrastructure $[11,24,25]$ have contributed to the increasing trend of indiscriminate dumping of waste in the country. Moreover, because of the lack of inadequate research and developmental activities in Liberia, there are a limited number of articles available regarding municipal solid waste disposal. Nevertheless, in recent years there have been some studies conducted regarding the environmental challenges in Liberia. In 2017, a study conducted by Wilson, S.T.K. et al. [26], on the mining sector: current practices and environmental challenges, revealed that industrial mining is associated with various environmental impacts 
including pollution, land degradation, loss of biodiversity, and contamination of underground water. Furthermore, a study conducted by McAuslan P [27], on urban planning law in Liberia revealed that the 14 years of civil war resulted in infrastructure damage particularly in the capital, Monrovia-and most facilities that escaped severe damage are deteriorating because of maintenance deficit coupled with rapid urbanization which has led to increased waste generation, thus stressing the already fragile waste management system [27]. Similarly, the EMUS, [17] report revealed that Liberia will need substantial help from its development partners-over a longer period than anticipated—regarding its waste collection services, recycling activities, and final disposal.

Previous researches have attempted to study both the growing increase in waste generated in Liberia and the environmental impacts. Nonetheless, there is less research conducted in Liberia to assess the existing waste management practices, recognize emerging waste management activities, over and above the challenges associated with waste management activities to propose effective waste management methods. Although many industrialized countries have made progress in sustainably managing their waste by adapting innovative techniques to ensure waste recovery, and developing guidelines regarding the management of waste, in Liberia, like most least developed countries, the management of waste has not been adequately prioritized and waste collection, treatment, and disposal remains largely ineffective [17]. Over the years, several methods for managing waste, including the 4Rs: reduction, reuse, recovery, and recycling, have been adopted by nations and implemented to minimize public health and environmental threats. However, this is still lacking in Liberia. This paper attempted to describe the current waste management practices in Liberia, analyze the regulatory and legislative frameworks, and establish stakeholders' actions that have the responsibility in waste management in Liberia. This study also analyzed the challenges to effective waste management in Liberia, highlighted the importance of adequate waste management, and suggested options for sustainable waste management. The main impact of this review was to support policy and decision-makers to restructure an efficient waste management scheme by establishing a framework for the development of an effective and sustainable waste management system in Liberia and other developing countries, arguing for the adoption of environmentally sustainable solutions for MSW management, and encouraging future research. To carry out this study, a critical review was conducted and information was obtained from published articles; official government documents and websites; other waste management sources including books, national and international conference papers; and internet documents, (e.g. the Environmental Protection Agency of Liberia, Ministry of Health, Liberia websites, etc.). Various policies related to waste management were also analyzed and field observation was carried out. The study observed and identified several challenges to practices and procedures regulating waste management. The analysis of Liberia's existing environmental policy permitted the identification of ineffectiveness of waste disposal activities and practices in Liberia.

\section{Sanitation from an MSW perspective}

Sanitation refers to the provision of services and the availability of facilities for the safe management of human excreta containment, storage, treatment, and safe disposal [28, 29]. The word'sanitation' from an MSW perspective can have different connotations and denotations depending on the context or location [29]. In this context, sanitation refers to the safe disposal and proper treatment of solid waste-by the term solid waste, we refer to items including garbage (plastic/glass bottles and cans, used clothing, manure, disposable items, food casings and scraps, and newspapers) including urine and excrement. Sanitation, therefore, applies to the preservation of hygienic conditions through the provision of services including waste collection and wastewater disposals [30].

\section{Sanitation in Liberia}

The current trend of sanitation in Liberia is described as a "Deadly Gap" by the Joint Monitoring Program (JMP) for water delivery and sanitation [31]. Reports from JMP, [31] showed that just 25 percent of the population have adequate access to clean water and 15 percent to adequate sanitation services. It was further reported that 18 percent of deaths in Liberia are associated with diseases caused by inadequate water and sanitation [31]. This low coverage of improved sanitation is due in part to the fact that the facilities are non-existent or may not be hygienic and convenient.[31]. It must also be noted that there is a wide difference in access to sanitation between the counties in and within suburban areas and between rural and urban areas. For example, in Mamba Point, Sinkor and other high economic enclave of Monrovia, effective sanitation is only accessible to 35 percent of the population, while in the Grand Kru County, Maryland County, Soniwein, and other slum communities the corresponding proportion is less than 3 percent [31]. The review further revealed that sanitation issues are mainly concentrated in urban economic areas, while the poorest coverage is in the overpopulated slum and rural communities [31]. 


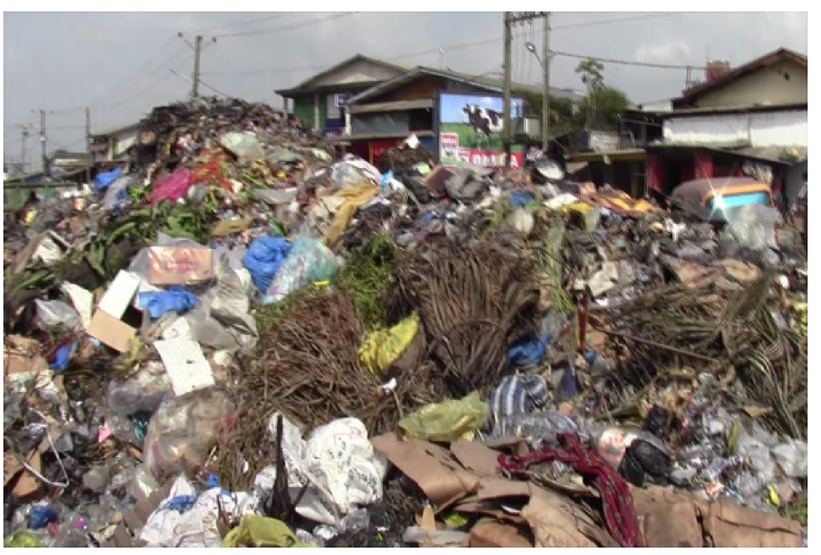

Fig.1 Urban zone view of open dumping of waste on the main Street of Doula market, Liberia observed (January 22nd 2019)

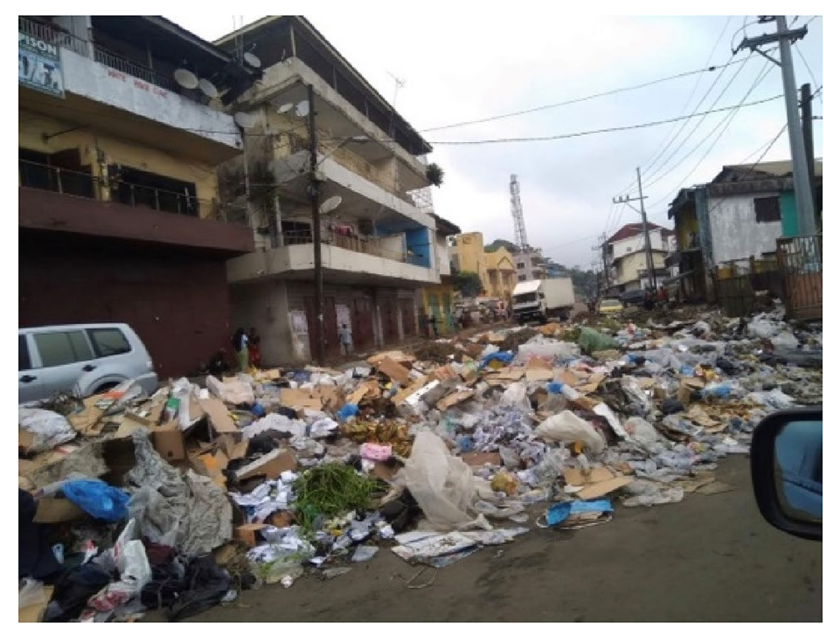

Fig. 2 Waste dumped on the road-side and street corners in Liberia, Urban zone, Johnson street (Observed on 4/17/2019)

\section{Field observations}

Site visits at various locations in Liberia have shown that open dumping is widespread and normal. The photos below show a typical scene of waste disposal on the streets in urban areas comprising waste from households and markets; these include plastic and other debris scatters in the streets and neighboring spaces as shown in (Figs. 1, 2 and 3). Most residents acknowledged there is an issue with solid waste management in Liberia and it requires urgent attention. Most Liberians, regardless of their socioeconomic status, are very concerned about the waste management activities in the country and often take to social media to give feedback or vent their frustration about the need to improve the system for managing solid waste.

Conversely, Figs. 4 and 5 show scenes of rural communities without sight of waste. This could be explained by

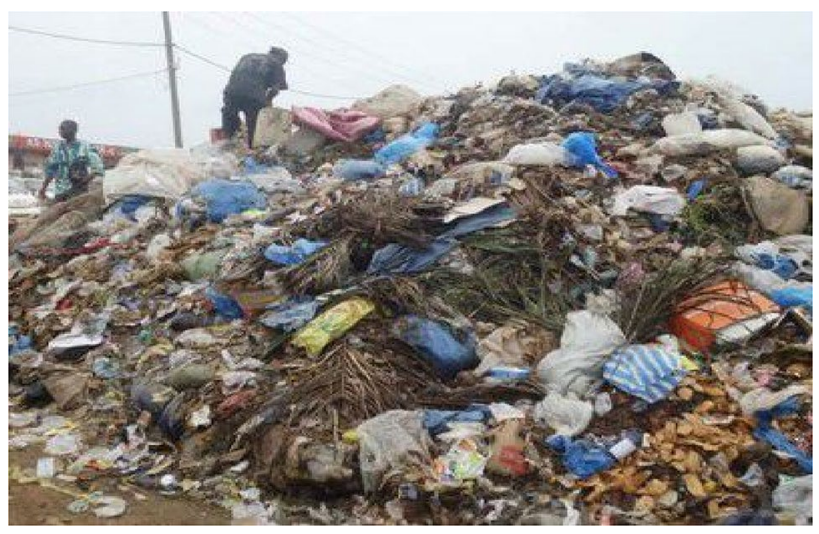

Fig. 3 Typical scene of road side waste in the Red-light district, Monrovia, Liberia (Observed on 02/20/2019)

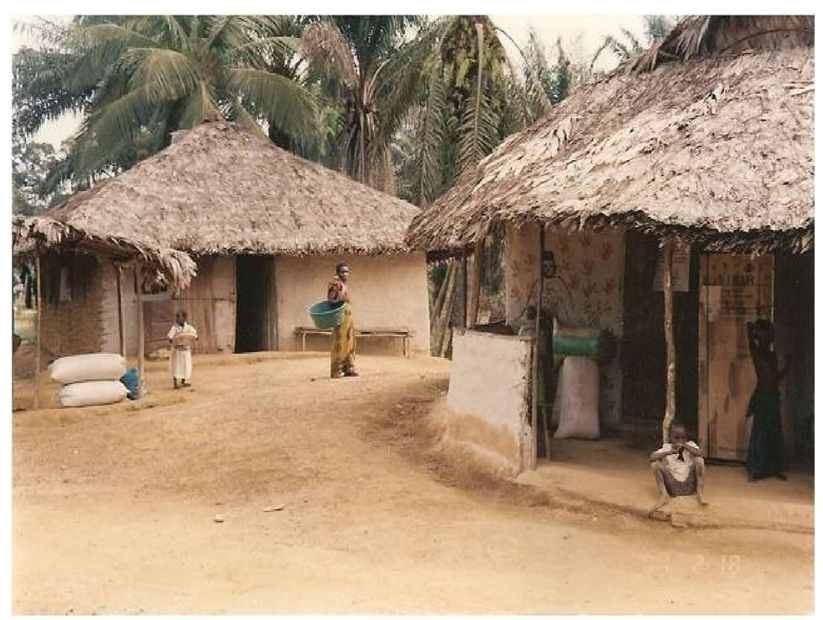

Fig.4 Typical scene of a rural community (Town of Gbor), Monrovia, Liberia without sight of waste, (Image courtesy of Bread for ALL). (Observed on (4/17/2019)

the variation of solid waste production per capita in rural areas compared to that of urban areas and/or residents' attitudes towards environmental sanitation. Additionally, the waste composition, waste density, and generation rates of solid waste in rural communities are of lesser quantity than in urban areas, [11, 32]. Further research is needed to fully understand the factors influencing waste generation in urban and rural areas of the country. The availability of data is also crucial to planning waste management programs and management operations. However, rural and urban areas in Liberia are still faced with the issue of data unavailability regarding waste generation and composition, which is a fundamental problem faced by most developing countries in effectively managing waste. Therefore, this review recommends further studies to understand the 


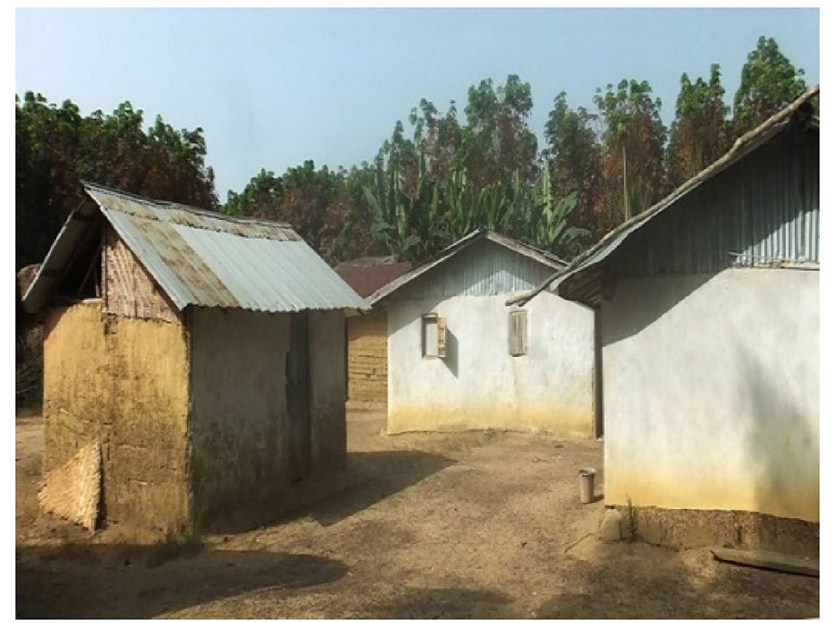

Fig. 5 Scene of a rural community without sight of waste (Observed on (4/17/2019) (Observed on (4/17/2019)

characteristics of the waste stream, quantity generated, and disposal systems in rural communities in Liberia.

\section{Regulatory and legislative frameworks}

To effectively manage waste, developed countries have formulated policies, enforced legislations, adopted and implemented best practice management, i.e. [Integrated Sustainable Waste Management] (ISWM), [24] approach which serves as an effective tool for operations and guidance of waste management, waste collection system, designing and implementation of innovative technologies]) system to manage waste [14]. Many European countries, for example, have adopted "zero waste Europe"' (ZW)—a plan that emphasizes converting waste to resources, encouraging treatment plants that include facilities for sorting recyclables, adopting WtE treatment processes, [8] the incorporation of incineration and composting plants, etc.[11]. However, most developing countries including Liberia are falling behind because of the lack of resources, lack of technical and technological skills, weak legislation, etc.[16, 31, 33].

Liberia has never had a comprehensive waste management plan but has promulgated various governmental regulations for supporting MSW management as shown below in Table $1[10,12,15,22,23,34-36]$. Liberia is a signatory to several protocols aimed at sustainable waste management. Furthermore, Liberia has ratified conventions for ecological protection, safety, and reduction of public health threats. However, many of the earlier policies and legislative provisions on waste management are not explicit. For example, the 1973 Act of the Republic of Liberia grants municipal governments a "Charter" status, authorizing them to enact the relevant local laws and ordinances for city administrative purposes as may be required. The Public Health Law of 1975 also calls for safe, clean, and sanitary environment for all, but is vague on the issue of managing solid waste [15]. Such inconsistencies breed impediments in clearly defining waste management activities and practices which have resulted in indiscriminate dumping of waste. To affect change in waste governance and management in Liberia, strategic planning of waste management programs incorporating all stakeholders is essential to ensuring efficient and effective waste management operations.

The absence of a legal framework to manage waste in Liberia is a major challenge to managing MSW. Waste is being indiscriminately dumped on street corners and bodies of water whilst landfilling is the most used method of waste disposal in the country $[33,37,38]$. This is a result of the lack of skilled technical human capacity for the development of a sustainable waste management plan; inadequate budgetary allocation for effective waste operations; a lack of adequate waste minimization facilities, sorting and storage; inadequate collection system; inadequate funds to support and establish waste management strategies; and the absence of technologies for solid waste disposal [25]. The absence of these factors has resulted in the improper collection of waste, inadequate disposal of waste, and environmental threats. Researchers David Jr Victor E. John Y., \& Wenchao J [15] and David Jr Victor E. Wenchao J., \& Mmereki D [16] have observed that sustainable waste management in Liberia requires basic education provided through national educational programs and the formation of a skilled technical workforce. The formation of this technical workforce will pave the way for the identification of problems within the current system, options for improvements, priorities to address problems, resources needed for operational activities, and the selection of appropriate treatment options.

Key institutions which are responsible for managing solid waste in Liberia are the Environmental Protection Agency, the Environmental and Occupational Health Department of the Ministry of Health and Social Welfare, the Ministry of Public Works (MPW), the Ministry of Lands, Mines, and Energy (MLME), the Monrovia City Corporation, etc., as summarized in Table 2 below. In Liberia, the Environmental Protection Agency (EPA) is charged with the executive authority to oversee all environmental activities and programs relating to environmental management $[12,38]$.

The Ministry of Health and Social Welfare's division of environmental and occupational health is responsible for environmental issues in collaboration with the EPA. Amongst other agencies, regional planning is directed by the Ministry of Planning and Economics Affair, while the Ministry of Public Works has a mandate to ensure clean drinking water and adequate sanitation. The National Environmental Policy Council of Liberia is the policy-making body of the environment, whilst the Monrovia City Corporation is 
Table 1 Policies, and legal protocols linked to the management of MSW in Liberia

Policy Objectives

The Draft Policy: National Healthcare Waste Management Policy, 2009

Environmental Protection and Management Law

The public health law of Liberia, 1975

National Health Policy and Plan, Liberia

National Environmental and Occupational Health Policy, 2010

National Environmental Action Plan

National Biodiversity Strategy and Action Plan

The Convention on Prevention of Marine Pollution by Dumping of Waste and other Matter, 1972

Basel Convention on the Control of Transboundary Movements of Hazardous Wastes and Their Disposal

Treaty on Marine Life Conservation, 1996
Objectives

To minimize adverse effects of healthcare wastes on human health and the environment

Ensure air quality standards and solid waste management as well as a draft legislation on Persistent Organic Pollutants', and 'Waste Management'

Section 21.1 specifies that improper management of waste results in adverse health effects which are prohibited by $\S 21.2$. Chapter 24 regulates liquid waste (water pollution control)

To reform the health sector and efficiently deliver quality health and social welfare services to the people of Liberia

To improve health and social welfare status and equity in health

To strengthen existing guidelines/standards in Basic sanitation, water quality control, food safety, vector control, port, health, human habitat, waste management, communicable disease control for the protection and promotion of public health services in Liberia, in collaboration with key stakeholders

To establish a framework for inter-sectoral coordination of environmental health policies and activities

Contain all matters affecting the environment and provide general guidelines for the management and protection of the environment and natural resources of Liberia well as the strategies for preventing, controlling, or mitigating any deleterious effects

To sustainably use biodiversity on a long-term basis to meet the requirements of present generations without endangering the potential of future generations to meet their own needs

Produce every five years as a guide for development planning and decision-making and is an important reference for environmental education and awareness

It was developed to serve as a monitoring tool for measuring progress against stated development goals

Promotes the effective control of all sources of marine pollution and to take all practicable steps to prevent pollution of the sea by dumping of wastes and other matter

To eliminate the risks arising from the transboundary movements of hazardous and other wastes

Source: Adapted from [10, 12, 15, 22, 23, 34-36]

responsible for enforcing city ordinance and management of municipal wastes $[38,39]$. It can be seen in Table 2 that these organizations have various MSW management mandates.

However, these organizations, agencies, and departments also have overlapping roles without specifically assigning responsibility for solid waste management activities, thereby impeding efficient waste management planning [15]. Furthermore, the inadequate collaboration between government agencies and stakeholders at various levels of government is impeding the effectiveness and sustainability of MSW management [32]. Additionally, the integrated approach to solid waste management (ISWM) is also lacking in Liberia. This serves as a hindrance to tackling MSW management issues because of the lack of strategic planning which is a core element of the Integrated solid waste management approach (ISWM) [40]. One of the many challenges to effectively manage waste in Liberia has been the lack of national commitment and political intent regarding waste management operations. Researchers Abdoli et al. [41] stressed that implementing waste policy is influenced by political intent and the desire of leaders. MSW management issues, therefore, need to be included in political parties' agendas and platforms-outlining their plans to protect the environment and public health $[24,42$, 43].

To summarize, in Liberia, cooperation between the different levels of government, effective planning of waste programs to maximize the effectiveness of waste management activities, prioritization of the integrated method for handling solid and hazardous waste, and approaches tailored to minimizing potential risks to health and environment are vital. Moreover, there is a need for in-depth research to fully understand the factors that affects the existing management 
Table 2 Institutions with MSW Responsibilities in Liberia

\begin{tabular}{ll}
\hline Institutions & Roles and responsibilities
\end{tabular}

Environmental Protection Agency, Liberia

Management of the environment and to coordinate, monitor, supervise, and consult with relevant stakeholders on all activities relating to the protection of the environment and sustainable use of natural resources

Setting up national guidelines for solid waste management in Liberia, environmental quality standards and ensuring compliance for pollution control

Providing guidelines for the preparation of environmental impact assessments (EIAs), audits/inspections and environmental licenses/permits for healthcare waste treatment plants

The Environmental and Occupational Health Department of the Ministry of Health and Social Welfare, Liberia

The Ministry of Public Works (MPW), Liberia

The Ministry of Lands, Mines, and Energy (MLME), Liberia

Monrovia City Corporation

National Environmental Commission of Liberia

National Environment Policy Council
Assess the environmental health of the population, thereby conducting sanitary inspections to evaluate compliance in line with the Public Health Law of Liberia

Installation of infrastructure for waste management delivery services, i.e. Waste collection to transfer stations and the construction of sanitary landfills

Evaluating urban sanitation projects

Providing guidance for engineered landfill sites for the disposal of nonhazardous waste generated from Healthcare facilities

Responsible for carrying out city ordinances, management of municipal wastes, recreation, public education and awareness and provision of services in environmental health and sanitation

Responsible to creates and promotes environmental awareness; develop a national environmental policy, environmental protection, and management law. Coordinates the activities of environmental related organizations, including NGOs and oversees international environment-related conventions

Responsible for policy making regarding the environment. It also set priorities for national goals and objectives for the protection of the environment

Promote co-operation among Line Ministries, local authorities, the private sector, non-governmental organizations engaged in environmental protection programs and the public

Source: Adapted from [12, 23, 34, 35, 38]

practices and the development of a viable system for managing waste [14, 24].

\section{Characteristics and composition of waste in Liberia}

Several studies have shown that solid waste is generated daily from a variety of sources, ranging from households, commercial establishments, industries, and municipal activities [9, 44, 45]. The characteristics and composition of the waste stream depend on several factors including income, standard of living, changes in patterns of consumption, etc. The classification of waste is also paramount to understanding the characteristics of the waste stream [9]. A study conducted in Liberia by the World Bank revealed that waste is categorized into various categories: general waste, infectious waste, hazardous waste, and radioactive waste [22]. Similarly, a study conducted by UNEP [23] found that waste is sub-divided into categories: organic (food scraps, papers cardboard, wood): inorganic waste (plastics, cans, bottles), and electronic waste (metals). Also, a recent study on the influencing factors of increased household waste generation conducted by [16]

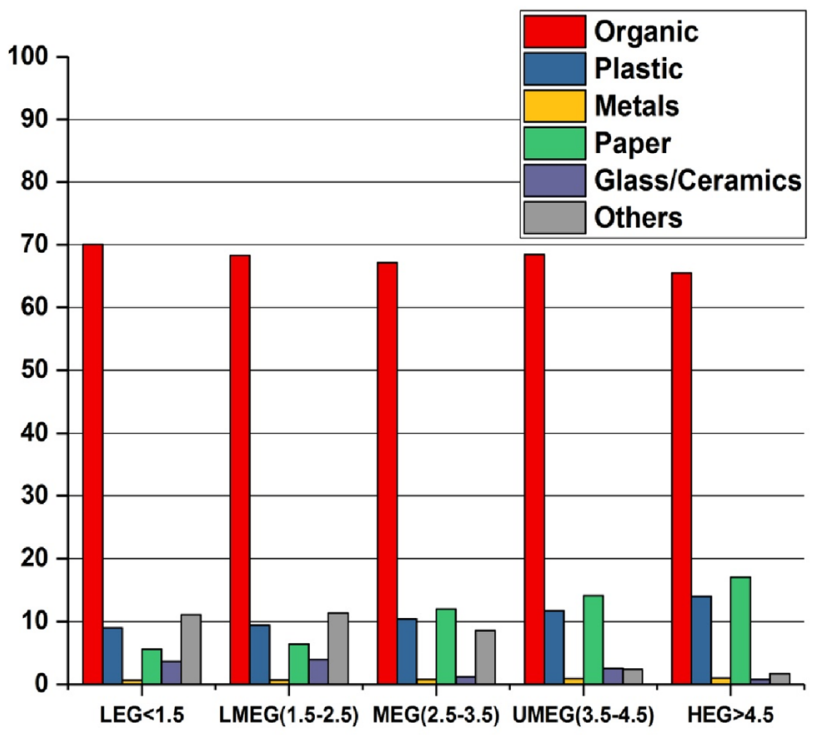

Fig. 6 Composition of waste generation by different income groups in Monrovia, Liberia 
in the city of Monrovia, Liberia selected households based on their socio-economic status and their monthly income per capita. See Fig. 6. This mode of stratification generated five different income groups:

- Low economic group (LEG): monthly income $<\$$ 150,000 Liberian dollars (LD) (LEG)

- Lower middle economic group: monthly income between \$ 150,000 and 250,000 Liberian dollars (LD)(LMEG)

- Middle economic group: monthly income between \$ 250,000 and 350,000 Liberian dollars (LD) (MEG)

- Upper middle economic group: monthly income between \$350,000 and 450,000 Liberian dollars (LD) (UMEG)

- High economic group: monthly income $>\$ 450,000$ Liberian dollars (LD) (HEG)

The results showed the composition of waste by households of different income groups. The study results further showed that waste generated by these diverse income groups varied from one household to another, as shown in Fig. 6 [16].

Generally, waste in Liberia is collected and managed to some extent. However, the collection and management system is inefficient and ineffective. One of the major challenges to MSW is the absence of sufficient and accurate data regarding the physical and chemical composition of waste and the quantity of waste generated throughout the country, thereby restricting comparisons with developed and underdeveloped countries. Moreover, the lack of a sustainable approach for source separation is also a challenge because of the absence of appropriate infrastructure, etc. which has led to unsustainable waste management practices, i.e. the lack of biodegradable utilization which tends to increase the volume of waste content in the waste stream. The development of an effective and sustainable waste handling system requires the conduct of a comprehensive study regarding the composition and quantity of waste produced [46].

\section{Municipal solid waste collection and storage}

Municipal solid waste collection requires an effective and efficient system based on the integrated approach to solid waste management (ISWM), which represents an existing systematic technique to managing solid and hazardous waste $[21,43]$. According to the World Bank Report, [6] primary waste collection in Liberia involves door-to-door waste collection services from households, institutions, etc. to skip buckets or communal dumpsters. However, waste collection and storage are still faced with inadequacies resulting from the irregular collection, lack of specialized containers, lack of an efficient household collection system, and the absence of a system for waste separation [22, 23]. See Fig. 7 (Waste Collection \& storage container). A recent study conducted

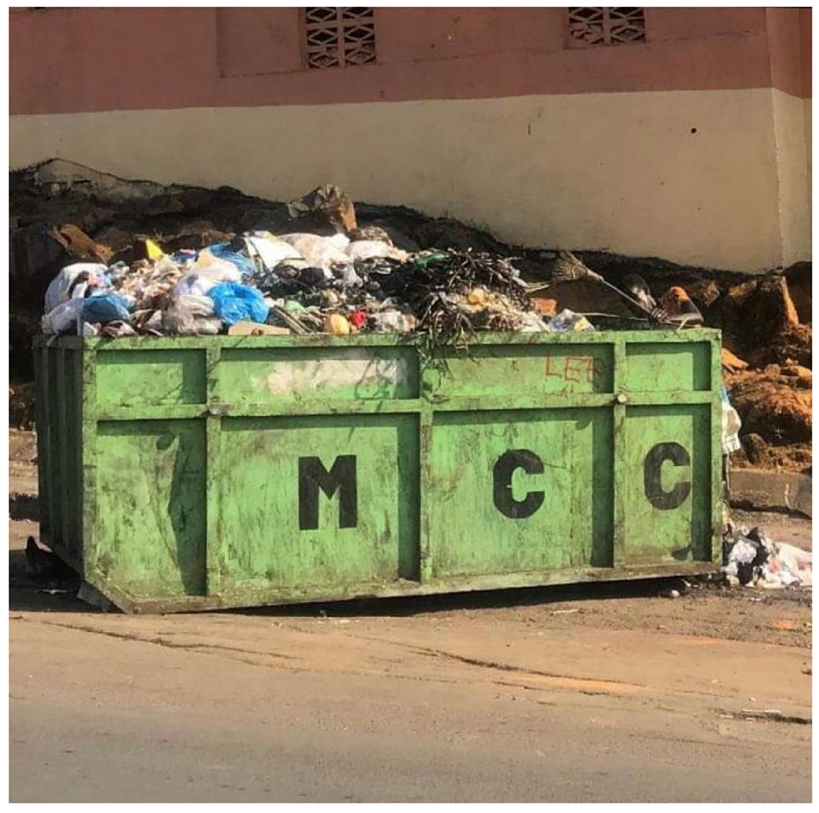

Fig. 7 Waste collection \& storage container

by the World Bank [6] revealed that about 800 tons/day of solid domestic waste per day is generated in Monrovia, representing roughly 45 percent of the total waste produced in Monrovia. The remaining, however (around 55 percent) remains uncollected or is not covered by the solid waste collection system. This, in turn, is due to the high costs and difficulties in collecting large quantities of waste generated by different establishment, i.e. households, business, etc.

The city corporations are responsible for waste collection services in most cities in Liberia, or at times subcontracted private companies. In some urban areas of Liberia, households are expected to pay a fee for waste collection services, whereas in some urban-rural or rural areas there is a complete absence of waste collection services, and, if available, collection services are rendered free of charge due to the public's unwillingness to pay. The collection of waste is irregular and there is an absence of a specific weekly schedule for waste collection. Furthermore, MSW services (collection up to final disposal) remain largely ineffective [15].

Waste is usually stored in metal drums, containers, plastic bags, or open bins in residential and commercial areas. However, the collection bins and containers used in the country are not labeled; thus organic and inorganic waste are mixed leading to an increasing volume of waste being sent to landfills. The mixing of waste produces threats to the environment in the form of leachate. Additionally, pollution from landfills also poses significant threats to the environment and to public health. Similarly, waste bins are improperly designed, situated, and maintained which has led to low collection efficiency [15]. MSW average collection efficiency is nonexistent in Liberia's cities and counties. The absence 
of waste characterization and quantification in most cities and rural areas in Liberia is a core issue that needs to be addressed. In most cities and suburban areas in Liberia, the lack of facilities for waste storage and the absence of waste segregation hinders the collection and storage effectiveness. Storage bins are mostly overflowing because of the lack of segregation of waste. In most municipalities in Liberia, the development and implementation of waste separation is absent due to the lack of facilities for sorting and storing waste. As a result of this, compostable materials, recyclables, hazardous, non-hazardous, etc. are continuously mixed. This situation has resulted in the accumulation of waste dumped along street corners, drainages, rivers, and swamps thus posing environmental and public health risks [15]. To provide a sustainable collection system for MSW, priority should be given to the adoption and execution of waste separation schemes at all levels, especially at the household level.

This review further revealed that the separation and sorting of waste is carried out on a low scale by the informal sector. This informal sector engages in the collection of recyclable materials from households or piles of waste at disposal sites. Waste collected by these scavengers is then sorted and sold to companies and factories in neighboring Guinea and Ivory Coast [35]. Studies have shown that with funding and support from the central government, the informal recycling sector has the potential to help improve waste recovery and separation systems as well as minimize the amount spent for managing waste [47, 48]. If Liberia is to improve its waste management through waste recovery programs, adequate funding and collaboration with the informal sector are required. A study by Remi de Bercegol et al. [49] revealed that the informal sector tends to decrease the volume of waste that goes to landfills. Nevertheless, even with the emergence of the informal recycling sector in Liberia, it is yet to be established how it could be best institutionalized and improved to reduce waste. It is, therefore necessary to introduce training programs for staff on waste minimization, raise awareness of waste sorting, segregation, and conduct education awareness campaigns on sustainable waste practices in line with global best practices for the effective management of MSW.

\section{Waste transportation}

The transfer of waste is an integral component of an efficient waste management program. This involves the provision of clear transportation routes, improved point-to-point routing, availability of disposal facilities within a proximate distance, and the provision and maintenance of adequate specialized vehicles [50]. Waste transportation in Liberia is usually carried out when households, commercial establishments, and institutions have collected and stored waste in open spaces, metal drums, open bins and plastic bags at various

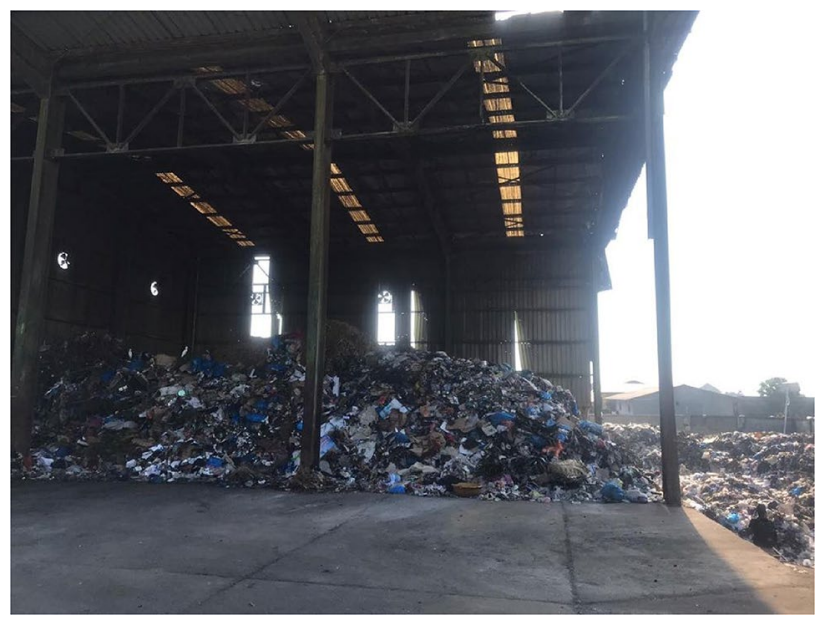

Fig. 8 Showing the waste transfer station in Liberia

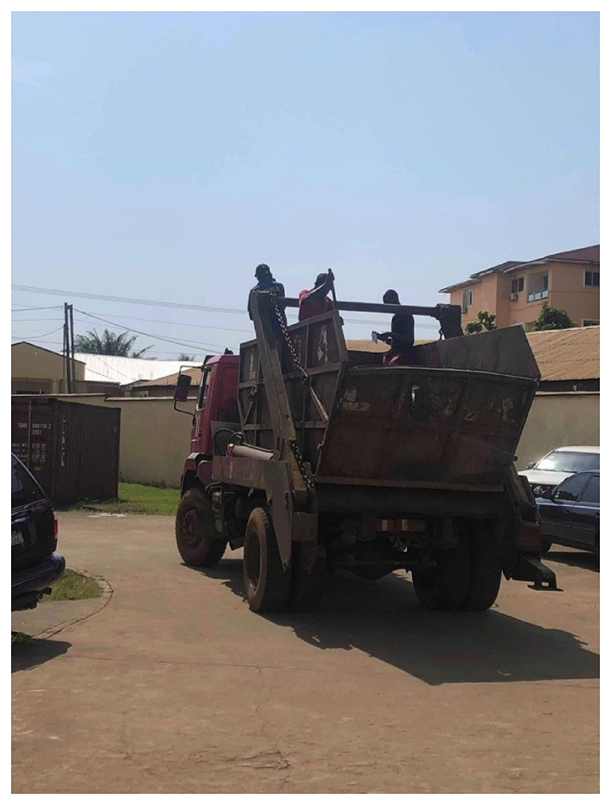

Fig. 9 Showing the waste collection vehicle

collection points or street corners and are then transported to the landfill or dump sites $[6,16]$. The City corporations in urban areas along with sub-contracted private companies carry out municipal solid waste transportation. These entities are responsible for the transport and disposal of waste in the country. This review, however, observed some challenges facing the transportation of MSW in Liberia. These challenges include insufficient specialized collection vehicles, hauling distance, collection time, collection route, inadequate transfer stations, etc. which have led to waste being inadequately disposed of. See Figs. 8 and 9 showing the waste transfer station and waste collection vehicle. Another challenge observed is at the point of collection. 
Waste collected by municipal collectors is not sorted and recyclables are often mixed and transported to disposal sites, resulting in the loss of potential recyclables. Similarly, compostable and recyclable materials are disposed of at landfills or disposed of indiscriminately in undesignated places. This, in effect, contributes to higher waste volumes. Furthermore, the quantity of waste to be handled may increase along with the cost associated. Adopting the recycling approach will decrease amount of waste sent to landfills, increase economic growth, and also reduce the cost of managing the remaining wastes [51]. This situation has also been observed in several other developing countries (e.g. Nigeria, Kenya, Sierra Leone, etc.,) as seen in the study conducted by Johannessen, L.M. and Boyer, G.[33]. This review also observed the challenge of long travel distance to disposal sites. In Liberia, the landfill is located on the outskirts of the capital, approximately $25 \mathrm{~km}$ northeast of Monrovia, and it takes about $2 \mathrm{~h}$ for a skip truck to make a round trip [17]. This often leads to leakages along the routes during the transportation of waste to the landfill.

The effectiveness of a sustainable waste transportation operation can only be achieved through improved vehicle routing for the transport of MSW, the provision and maintenance of adequate specialized vehicles, regular training of waste handlers, reduction of waste travel distance to disposal sites, the optimization of material recovery, and the decentralization of waste management services.

\section{Treatment and disposal}

Liberia is still struggling to implement a sustainable waste management system, i.e. selection of appropriate treatment methods, legislation, infrastructure, etc. In Liberia, the most practiced methods of waste disposal are open dumping, open burning, waste burial, and landfilling which is typical for most developing countries [12, 15, 22, 23, 50-52]. In Liberia, the absence of MSW treatment facilities and adequate disposal facilities is still a fundamental problem.

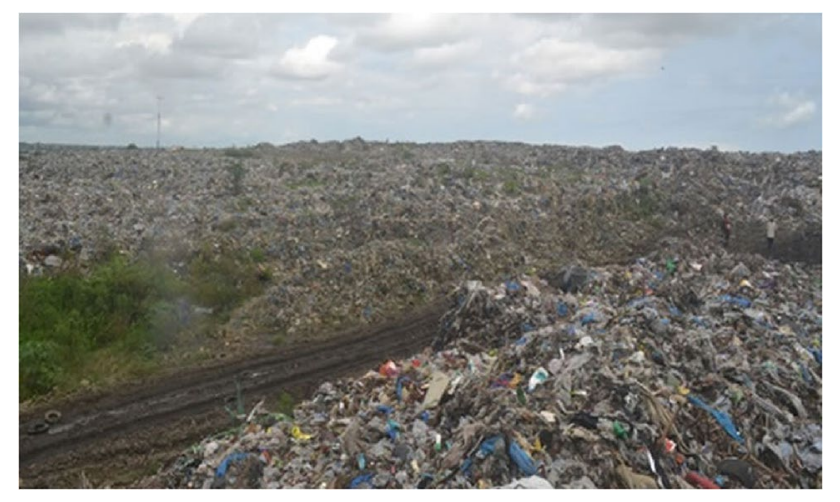

Fig. 10 Showing the landfill site in Liberia
It is worth noting that landfill disposal activities are limited to very few cities in the country. Landfills in Liberia are not adequately engineered, i.e. the absence of leachate and gas collection system [16] Fig. 10 Landfill site. This particularly is because of the lack of funds, lack of research regarding suitable methods for treating and disposing of waste in an environmentally friendly manner, lack of policy enforcement, etc. which could result in leakage from the landfill to its surroundings and causing contaminations [53-55]. A similar finding was reported from a study conducted by Ranganai RT, et al. [54] in Botswana which showed that leakage from an inadequately engineered landfill resulted in potential threats to underground water and the environment. More effort is needed to increase public awareness regarding the management of waste sustainably, proper planning of SWM programs, and the design of engineered sanitary landfills.

Pre-treatment methods including composting, anaerobic digestion, etc. are generally non-existent in Liberia. Moreover, waste disposal of relatively high organic loading and toxicity remain in the environment for a long period of time because of low organic removal efficiency [56]. Engineered sanitary landfills are non-existent within the country for the disposal of hazardous waste. The most common form of landfilling practiced is open swamp filling, which is unsustainable. Similarly, due to the lack of adequate public awareness about waste management, medical waste is occasionally disposed of in open areas. A study conducted by V.E. et al., David [35] disclosed that at most health facilities, disposal sites are often within residential areas without proper controls and waste management procedures. In addition, medical waste incineration was well below expectations and, contaminants that could include dioxins and furans during incineration were released into surrounding communities and the general environment. A majority of the waste produces in cities, towns and villages is randomly mixed and disposed of together at random. The mixing of biodegradable waste with hazardous waste-i.e. medical waste - tends to contaminate the waste stream and

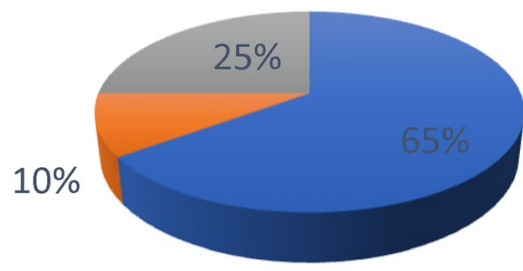

Indiscriminate dumping Open burning Landfilling

Fig. 11 Waste disposal methods in Liberia. Adapted from [15] 
poses severe risks to the waste handlers [56]. A study conducted by David Jr Victor E. Wenchao J., \& Mmereki D [15] on waste disposal in Liberia also shows the dumping of waste in water bodies, drainages, along street corners, open burning, and landfilling, etc. as shown in Fig. 11. Research conducted in developing countries has also reported similar findings of open dumping and burning as methods of MSW disposal in most developing countries which poses risks to health and environment [52-54].

The practice of indiscriminate dumping and open burning and burial of waste serves as a conduit for the spread of disease and poses threats to public health. Similarly, open waste burning releases large quantities of greenhouse gasses into the environment including $\mathrm{CO} 2$, methane, and particulate matter, which are usually associated with air pollution and can lead to serious cases of respiratory disease $[51,55,57$, 58]. This observation, however, is similar to findings from research conducted in Tanzania and Ghana on the effect of open burning of wastes [33]. Results from these studies further showed that such action of open burning of waste releases harmful substances which lead to pollution and global warming [33]. It is, therefore, necessary that the relevant authorities in Liberia adopt strategies to ban the practices of open burning, open dumping, and burial of waste, hence minimizing threats to the environment and health.

\section{Waste minimization}

An important step to minimize waste in Liberia is through recycling, reuse, and composting, thus reducing transport and final disposal cost, providing revenue from the sale of recyclable materials and positive gain in environmental impact. A small-scale recycling activity was initiated in Monrovia, the capital city of Liberia, in 2015 as reported by EMUS, [17]. However, this has not been scaled up and remains a tiny portion of the total waste disposed of. Approximately, this project has 1-3 transfer stations with built-in incentives for recycling. However, it is estimated that the material currently recycled is far below the recycling potential, which is estimated at around 40 percent. While this is the case, job opportunities that could have accrued mostly to unskilled labor, worst hit by the unemployment in Liberia, has remained untapped [17]. Recycling of waste in Liberia is also still in its infant stage. In Liberia, waste recycling is also carried out on a low scale by the informal sector and an absence of waste recovery [16, 17]. Recycling activities have been overlooked because of inadequate planning. Moreover, industries in Liberia are yet to employ innovative techniques for materials recovery, which has resulted in materials being recovered in an unsustainable manner, thus posing adverse threats to the environment. Additionally, Liberia is yet to develop recycling guidelines that will help improve the economy and generate jobs for waste pickers. Liberia, like most developing African countries, still considers recycling as the least favored waste disposal method despite the advantages associated with it [33], which also includes less usage of raw materials during production and extending the life-span of landfill sites. To effectively bring about changes to the management of MSW in accordance with global best practices, it is important to encourage reuse, resource recovery, and recycling of MSW. Similarly, the introduction of recycling incentives coupled with the enforcement of waste management policy should be prioritized. There is no easy solution to managing waste in Liberia. Nonetheless, since the problem is expected to deteriorate if nothing is done, steps must be taken to ensure that an efficient, reliable, and sustainable waste management system is developed.

\section{Waste management in Liberia and other developing countries in Africa: A comparison}

Several researches conducted over the years in developing African countries have shown that the management of solid waste was not given priority Dladla et al. [11]. Table 3 shows the status of waste management in developing countries in Africa. According to research conducted by Dladla et al. [11] the collection of waste in most developing African countries is usually seen as ineffective and the availability of data on waste production and composition still remains a challenge. Dladla et al. [11] also highlighted the absence of source separation and treatment, inadequate disposal and low scale recycling by the informal sector. Also, the development of sustainable waste management is still a challenge resulting in unsustainable practices i.e. open dumping and burning of wastes resulting in the loss of recyclable materials. In most developing African cities, access to excellent-road infrastructure might be found in city centers, with the roads in other suburbs being in a poor conditions $[59,60]$. Moreover, the waste service delivery models and methods could be different in diverse urban settings, as well as various cities and towns. The collection rate of waste remains ineffective and varies between cities. There is a tendency for waste collectors to frequently collect waste from high-income neighborhoods as compared to low-income or suburban areas [59, 61]. It is important to note that the important aspects of ISWM as outlined by several researchers includes the availability of statistics on waste production and composition, appropriate collection and source separation structures, as well as safe treatment and disposal systems [32, 62].

Alternative waste treatment like waste-to-energy (WtE) is virtually absent in Africa, with only a few successful projects Johannessen and Boyer [37], such as the eThekwini landfill gas (LFG) to electricity project in Durban, South Africa, which generates 7.5 MW of electricity from 
Table 3 Waste management in Liberia and other developing countries in Africa: A comparison

\begin{tabular}{|c|c|c|c|c|c|}
\hline Country & Collection and transfer & Recycling & Treatment & Disposal & Policy \& Legislation \\
\hline \multirow[t]{2}{*}{ Sierra Leone } & $\begin{array}{l}\text { Private sector \& Munici- } \\
\text { pality }\end{array}$ & $\begin{array}{l}\text { Private Sector and Munici- } \\
\text { pality }\end{array}$ & N/A & Open dumping & Weak regulatory framework; \\
\hline & $\begin{array}{l}\text { Inefficient \& Ineffective } \\
\text { collection }\end{array}$ & $\begin{array}{l}\text { Low scale recycling activi- } \\
\text { ties }\end{array}$ & & $\begin{array}{l}\text { Open burning [11] } \\
\text { Landfilling }\end{array}$ & $\begin{array}{l}\text { Weak enforcement of legis- } \\
\text { lations; }\end{array}$ \\
\hline \multirow[t]{2}{*}{ Senegal } & $\begin{array}{l}\text { Private sector and Munici- } \\
\text { pality }\end{array}$ & $\begin{array}{l}\text { Private sector and Munici- } \\
\text { pality }\end{array}$ & N/A & Open dumping & Weak regulatory framework; \\
\hline & $\begin{array}{l}\text { Inefficient \& Ineffective } \\
\text { collection }\end{array}$ & $\begin{array}{l}\text { Low scale recycling activi- } \\
\text { ties }\end{array}$ & & $\begin{array}{l}\text { Uncontrolled burning of } \\
\text { wastes [60] } \\
\text { Landfilling }\end{array}$ & $\begin{array}{l}\text { Weak enforcement of legis- } \\
\text { lations; }\end{array}$ \\
\hline \multirow[t]{2}{*}{ Mali } & $\begin{array}{l}\text { Private sector and Munici- } \\
\text { pality }\end{array}$ & $\begin{array}{l}\text { Private sector and Munici- } \\
\text { pality }\end{array}$ & N/A & Open dumping & Weak regulatory framework; \\
\hline & $\begin{array}{l}\text { Inefficient \& Ineffective } \\
\text { collection }\end{array}$ & $\begin{array}{l}\text { Low scale recycling activi- } \\
\text { ties }\end{array}$ & & $\begin{array}{l}\text { Uncontrolled burning of } \\
\text { wastes } \\
\text { Landfilling }\end{array}$ & $\begin{array}{l}\text { Weak enforcement of legis- } \\
\text { lations }\end{array}$ \\
\hline \multirow[t]{3}{*}{ Liberia } & $\begin{array}{l}\text { Private sector and Munici- } \\
\text { pality }\end{array}$ & Informal Sector & N/A & Open dumping & Weak regulatory framework; \\
\hline & $\begin{array}{l}\text { Inefficient \& Ineffective } \\
\text { collection }\end{array}$ & $\begin{array}{l}\text { Low scale recycling activi- } \\
\text { ties }\end{array}$ & & $\begin{array}{l}\text { Uncontrolled burning of } \\
\text { wastes [15] }\end{array}$ & $\begin{array}{l}\text { Weak enforcement of legis- } \\
\text { lations; }\end{array}$ \\
\hline & & & & Landfilling & \\
\hline
\end{tabular}

N/A not applicable

Source: Adapted from Source: $[11,15,23,60]$

two landfill sites $[59,63]$. Similarly, recycling of wastes in developing countries is usually carried out by the informal sector usually on a low scale and is the lesser favored disposal method even though it provides a suitable result for waste reduction. There is limited access to empirical data on recycling in most developing African countries because the collection of recyclables is usually carried out informally at the household level or by the informal sector [20, 29, 59]. The informal sector (e.g. purchasers and waste pickers) recover most of the post-consumer recyclables, such as ferrous metals, plastics, glass and paper, and supplies them to recycling companies [64]. Besides, the quantities of waste sent to landfill sites are usually high in developing countries particularly due to the limited recycling programs, the lack or absence of source separation, the absence of an effective and efficient collection system where organic waste should be selected and used for agricultural purposes.

Waste governance is a crucial part of creating and enabling environment for ensuring sustainable waste management [19]. One of the many challenges faced in developing African countries is the inability of governments to deal with the increase waste generation and develop policies, legislation, and strategies to effectively manage waste [65]. In addition, the legal structures for waste in most developing African countries are often fragmented and their municipal solid waste regulations are weak, without any clear distinctions between governments roles and responsibilities, service providers and waste generators [44, 59]. Research conducted by Ma and Hipel, [66] revealed that the effectiveness of any municipal solid waste management primarily depends on an enabling governance environment defined by social, economic and psychological factors, including public engagement, policy, and public attitudes and behavior.

\section{Challenges to MSW management in Liberia}

\section{Potential threats to the environment}

The poor management of solid waste in Liberia poses severe threats to public health and the environment [15, 23, 30, 55]. These factors tend to threaten the environment and health by causing pollution and the outbreak of disease. Although pollution has been linked to indiscriminate dumping, in Liberia, it has not been properly researched. Alternative approaches including planned landfills construction required collaborated efforts. In addition, the lack of skilled individuals with requisite knowledge of waste treatment systems and the lack of an integrated approach to waste management (ISWM) to address waste-related threats to the environment are among the many challenges faced in managing waste in Liberia. Liberia, like most developing countries, has well-formulated policies, but the implementation of these policies is still lacking [15, 16, 22, 58]. Moreover, Liberia has yet to take steps to mitigate threats to the environment and ensure an efficient waste management system is established. It is 
important that Liberia adopt best practices from industrialized countries like Japan [67], and developing countries like China that have employed the use of technologies including composting in their agricultural sector, reducing methane emission from landfills, and incorporating $\mathrm{WtE}$ technologies which provides energy in the form of power and the production of clean renewable energy, all of which have positive implications for the environment [48]. The adoption of these approaches in Liberia will guarantee the sustainable management of waste and transformation of waste into fertilizers to promote agricultural activities, the generation of electricity, the minimization of threats to the environment, and the creation of jobs.

\section{Lack of financial sustainability}

Studies conducted by Zohoori M., Ghani A [68] and Hussein I. A. Mansour M.S.M.[69], have indicated that the costs of managing MSW are a burden for most least developed countries due to the high costs associated. Their studies further revealed that high-income countries have prioritized recycling, adopted waste treatment technologies, and introduced levies on waste disposal to ensure the cost-effectiveness of managing waste. In Liberia, a major challenge to waste management development is the lack of financial sustainability for waste management operations and the lack of economic incentives. According to the World Bank report, [6] solid waste management in Liberia is grossly underfunded in the national budget. The report revealed that all budgetary allotment for solid waste management from 2015 to 2018 came exclusively from donors or counterpart funding linked to different environmental projects. A major problem facing the solid waste management sector is the lack of funds and high cost of collecting generated waste, with little or no budgetary allocation for waste management operations. In Liberia, the problem is acute especially at the level of the central government where the taxation system is inadequately structured, and the foundation for public services, including solid waste management, is weak [70]. Furthermore, in Liberia, the willingness of consumers to pay for services is extremely limited-which is typical for most developing countries-and their willingness to pay for services is inconsistent [70]. Further changes must be made in a financially sustainable way, and an efficient plan for raising funds to ensure financial sustainability must be adopted.

\section{Urbanization}

The population of Liberia has been increasing since the late 1980s, as reported by the Liberia 1984 census [52]. A total number of 2,378,272 residents are considered to be living in urban areas in Liberia [52]. In 2017, 50.7 percent of the total population of Liberia total lived in urban areas [71].
In addition, the World Bank report revealed that, [6], the population of Liberia has increased by approximately $71 \%$ since the end of the 14 years of civil unrest in the country coupled with increased migration of people to various urban centers of the country. The effect of urbanization has led to increased waste generation, and poor environmental conditions in various urban cities, etc. Over the years the increasing trend of urbanization has been visible in major cities in the country with the rate of urbanization at 3.24 percent [2]. As the population increases, there are consequences which become increasingly noticeable which can be classified in different ways, but is generally divided into two categories: geophysical and biological hazards [5]. The rapid urbanization growth provides key explanations for MSW as an acute problem to development. In most developing countries, poorly managed waste contributes to flooding by blocking drainage, increasing debris, and harboring vectors of disease [63, 72]. This inadequate disposal of waste may lead to drainage blockages [73] resulting in flooding [72]. The collaborated effort of all stakeholders is required to ensure proper planning and provision of waste disposal and treatment so that waste is treated at the source. This will reduce the burden and save resources.

\section{Institutional constraints}

In Liberia, several agencies are partially involved in the management of solid waste, e.g. the Monrovia City Corporation, the Environmental Protection Agency, the Department of Occupational Health at the Ministry of Health, the Ministry of Rural Development, and the Ministry of Public Works, among others. However, their roles and responsibilities are not clearly defined concerning the management of SW. There also exists a lack of effective corporation between relevant agencies resulting in resources wastage and the unsustainability of solid waste management programs [37].

Additionally, the lack of appropriate MSW compliance legislation is a major factor in the roles of the relevant agencies involved not being clearly specified, and the lack of collaboration between them. Liberia's legislation on solid waste management is inconsistent and fragmented and several laws (e.g. the Public Health Law of 1975, [36], Environmental Protection and Management Law, National Environmental and Occupational Health Policy, National Environmental and Occupational Health Policy, the National Environmental Action Plan, etc.) calls for a safe, clean and sanitary environment for everyone, but policy on solid waste management is vague [36]. Therefore, a robust legislation is needed that will fill the gaps of regulatory functions and sustainably enforce the management of MSW in line with global best practices. 


\section{Challenges to public-private partnership (PPP)}

Liberia has adopted a framework to manage concessions for extractive industries and natural resources. While this framework is strong in some regards, in other places significant gaps exists which limits its effectiveness [74]. Public-private partnerships in Liberia are not well established, especially when it relates to waste management activities. Specifically, public-private partnerships regarding designing of sanitary landfills, effective management of MSW waste, and a detailed national waste management plan are almost absent in Liberia. The absence of an established public-private partnership in MSW management in Liberia has resulted in the lack of skilled professionals with the requisite expertise from the private sector to provide their expertise, basic infrastructure i.e. landfills, waste transfer stations, low public participation, and limited public-private partnership experience. For the sake of comparison, private corporations hired by various cities in Brazil manage most sanitary landfills [75]. However, In Liberia landfills are managed by the government of Liberia along with the city corporations [15, 22]. It is recommended that the central government encourage public-private partnerships to attract private investors with expertise in waste management. Moreover, public-private partnerships should be considered for recycling services and the introduction of a private financing structure. Establishing public-private partnerships for MSW management will help address the infrastructure deficit, thereby providing needed services (i.e. proper transportation routes, transfer stations, engineered sanitary landfills, etc.) and increasing waste management efficiency [46].

\section{Strategic action plan for improvement of MSW management}

Numerous challenges to solid waste in Liberia include the absence of waste disposal facilities and the increasing trend of waste generated. In addition, large quantities of waste produced remained uncollected or haphazardly disposed, while portions of waste generated are disposed at the already filled landfill site located in Whein town. This seems to be a more acceptable option for waste disposal activities in Liberia, because of the country lack of capacity to make effective use of other alternatives, such as recycling or energy recovery, due to the lack of funds, lack of skilled individuals, etc. Nevertheless, this option, is down the hierarchy of waste as seen in Fig. 12 which prioritizes waste prevention at the top, followed by minimization/reuse, recycling, energy recovery, and safe disposal. Against this background, a phase approach is recommended for the adoption of the integrated method

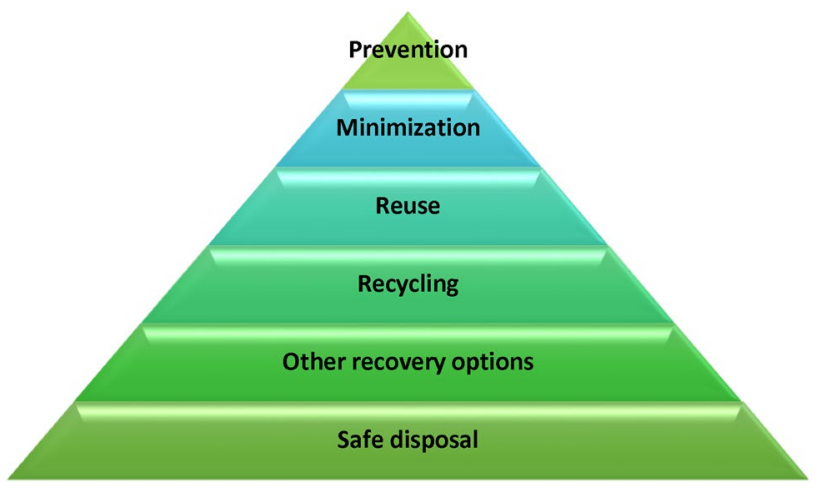

Fig. 12 The Hierarchy of waste management. Adapted from WASTE [76]

to solid waste management (ISWM) in Liberia to be used by the waste management sector as a guidance system. The adoption of this approach will ensure the prioritization of different methods of solid waste management in the order set out in the waste hierarchy [76].

To achieve improvements to the existing MSW management in Liberia, strategies have been formulated for adoption and implementation for effective management of MSW. This action plan is illustrated in Fig. 13.

\section{Suggestions relative to the strategic action plan: A phase approach}

A phase approach to implementation is a key element of a successful implementation plan because it helps overcome resistance to change, allows lessons learned in the early stages to be incorporated in the systems installed in the later phases, and ensures a solid foundation of the project [77].

I. The first phase to minimizing waste in Liberia should involve the formulation and implementation of a national waste management policy over a 5 -year period. The development of this policy should prioritize recycling, introduce recycling incentives, and seek to institutionalize the informal recycling sector [14]. Furthermore, the policy should also contain guidelines regarding the responsibilities of waste generators and stakeholders concerned with waste management operations. Additionally, the establishment of the policy should be based on the Integrated Solid waste management approach (ISWM), and should enable decision- makers to adopt healthier, safer and more efficient policies, facilitate public participation, institute educational programs at various schools and universities regarding waste management, encourage educational awareness campaigns regarding the adverse effects of waste on public and environment health when inadequately managed, and 


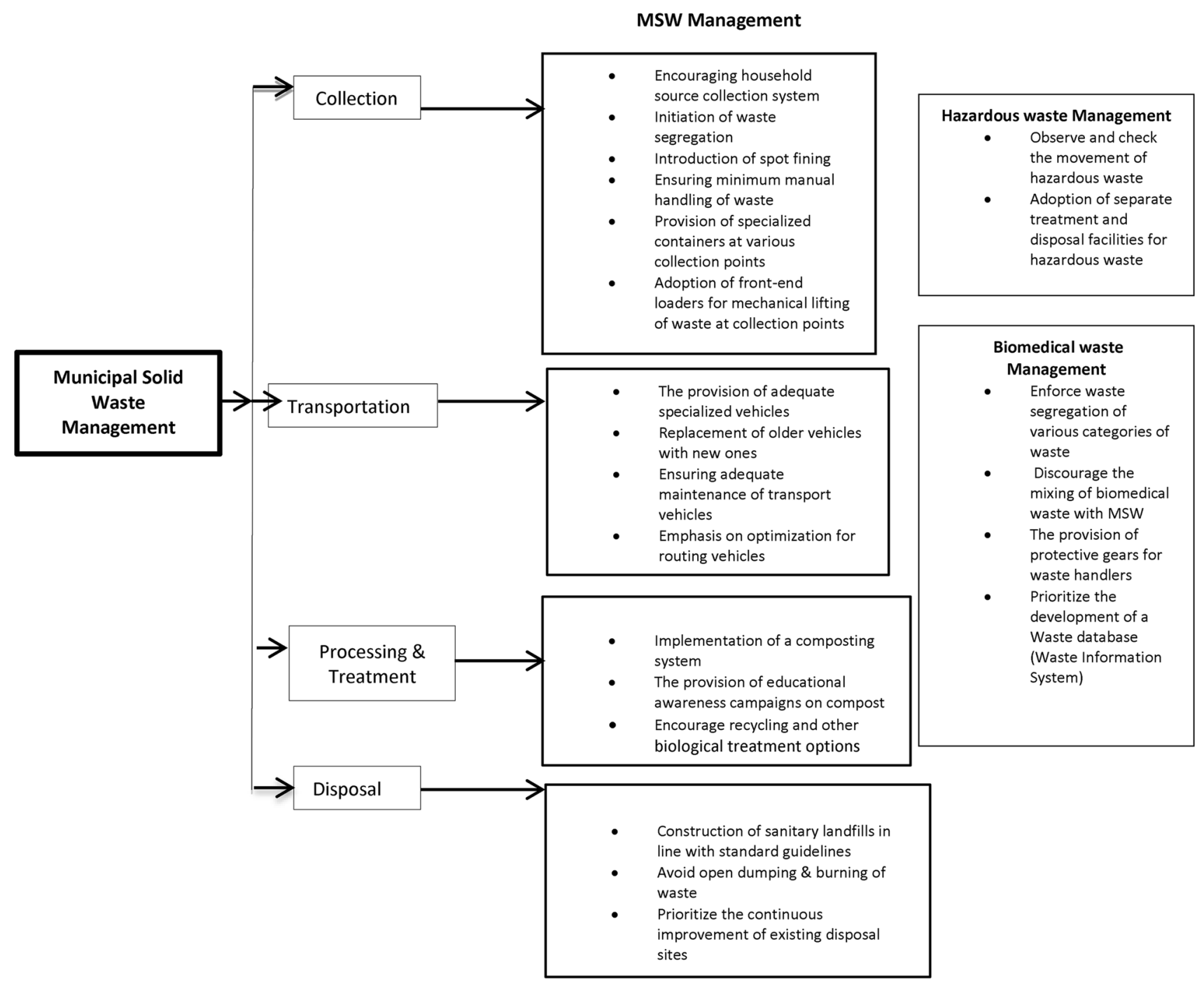

Fig. 13 Flow-diagram showing strategies for solid waste management activities in Liberia Modified from [Dladla F. Machete \& K. S [11], modified by the author

establish public-private partnerships to MSW management to attract private investors with expertise in the waste management field and improve waste facilities.

II. This next phase involves the identification of stakeholders involved in waste management-a short-term phase between 1-3 years. These actors involved are the municipal government (public sector), waste organizations (formal private sector), waste pickers and (informal private sector) that influence the provision of waste management activities. These actors are identified in municipalities and cities and are grouped accordingly. Stakeholders are usually different from one city to another, and thus need to be decided locally. They have a say in decision making, waste management plans, programs and setting, and defined roles and interest regarding the management of waste. When this is done, the drafting of a master plan should be prioritized which various municipalities could use to make decisions about the movement of materials as well as strategizing alternative solutions to waste effective collection (i.e. the provision of specialized vehicles for the transport and maintenance of facilities, safe transfer, selecting appropriate treatment including design of engineered landfill with facilities for weighing of solid waste and extinguishing of fire, a post for record maintenance, leachate and gas collection system for treatment, and a facility for source sorting, separation, and safe disposal [76].

III. This phase is concerned with the adoption of the Integrated approach (ISWM), a long-term phase between three to five years. The Integrated Solid Waste Management approach (ISWM) is a strategic initiative for the sustainable management of solid waste, through which 
the use of an integrated system generated through a sustainable, preventive, and consultative approach to the utilization of a variety of practices to effectively manage solid waste safely and appropriately. This system combines various sources, methods of waste collection, treatment, and disposal aiming to achieve environmental benefits, economic efficiency, and societal acceptance. This management scheme also includes waste minimization, the use of a number of different treatment and disposal methods, including waste reduction at source, product reuse, material recycling, energy recovery, landfill, incineration, and alternatives such as pyrolysis, gasification, composting, and anaerobic digestion in accordance with the waste management hierarchy.

IV. The ISWM also recognizes three essential dimensions of waste management: (1) stakeholders, (2) components of the waste system and (3) aspects of sustainability. Also, the basis on which the ISWM is based is the waste management hierarchy-a policy framework that is part of many national environmental laws and policies [78]. A study conducted in Liberia by David Jr Victor E. Wenchao and J., \& Mmereki D [16]. revealed that organic waste is dominant among the waste stream and therefore suitable for composting. Similarly, a study conducted in Ghana by Kodwo Miezah et al. [79] revealed that the organic waste fraction ranged from 48 to $69 \%$, the largest in the waste stream and recommended composting as a treatment method. The introduction of organic waste composting should therefore be considered to convert organic waste into useful agricultural products [24]. The implementation of the composting scheme should first seek to acquire baseline information necessary for planning, conduct a pilot program to collect compost from a variety of communities and institutions. Additionally, the use of adequate facilities is essential to ensure a sustainable composting scheme. Such facilities should have standard equipment, protective equipment, and requisite tools to effectively manage organic waste. The implementation of composting programs will be beneficial to communities in Liberia in the form of:

a. The extension of the lifespan of landfills reduces GHG gas emission and leachate;

b. The provision of jobs and the creation of usable and sellable products that can be used for horticulture, agricultural, and landscaping purposes $[11,80]$.

The adoption of the Integrated approach to solid waste management will greatly help the waste management sector in Liberia as this system has proven to be a leading concept to efficient waste management employed by developing countries in Africa [81]. Ideally, this concept was primarily designed to address challenges to sustainable waste management in low and middle-income countries and emerging economies [76].

\section{Conclusions}

The municipal solid waste management sector in Liberia is faced with immense challenges and growing concerns regarding the inadequacies of waste management activities in the country. This paper sought to describe the existing management practices and challenges impeding waste management activities in Liberia, provide information to the readers on the challenges posed by the development of a sustainable system for managing waste. Environmentalists and conscious minded citizens are becoming increasingly concerned about the appalling state of waste management in the country. This is due, however, to the lack of ineffective management, the absence or lack of implementation of a waste management policy, ineffective collection system, the absence of sorting and separation of waste, the absence of accurate data regarding the quantities and composition of waste produced, and inadequate measures taken to minimize environmental pollution. The major challenges to MSW management in Liberia range from the absence of an integrated waste management framework which has resulted in inappropriate disposal of waste, inadequate sanitary landfills, the ineffective collaboration between stakeholders, lack of public-private partnerships regarding waste management, the lack of implementation of waste recycling programs, and the lack of economic incentives, which is typical for most developing countries. The development of a sustainable MSW management in Liberia is further hampered by the lack of finances, technical, technological and policy support, low public participation, the lack of educational awareness programs, lack of training of staff, and the lack of recognition of the informal recycling sector. The author anticipates that this review will provide insight to planners, decisionmakers, and stakeholders to strategize an efficient framework for waste management in Liberia and help other developing nations improve their waste management systems.

\section{Recommendations}

The following are recommendations to improve the existing MSWM practices in Liberia:

- Encourage educational awareness regarding waste segregation at the source, and recycling of recyclable materials.

- Adopt the treatment of waste as a resource.

- Institute formal recycling of recyclables. 
- Encourage community engagements and full participation of all stakeholders involved in solid waste management operations.

- Provision of financial resources by the government to municipal bodies to encourage the effective management of MSW.

- Liberia needs to switch from a linear economy to a circular economy. The strategy for the future could include the following treatment methods of municipal solid waste: (a) landfilling in a sanitary manner, (b) adequate sorting and recycling; (c) composting, (d) anaerobic digesters (e) waste to energy (WTE) plants-or waste-energy (f) incineration with energy recovery, which should be selected according to the type of waste, amount of waste processed, applications, advantages and disadvantages, required investments, cost structure or tender process for contractors (fixed, variable, operational), costs of operation and maintenance, minimum installed capacity, the nature of the service provider, the amount of energy generated, logistics, and other information related to each technology.

- It is further recommended by the United Nations Environment Program to prioritize the safe management of household and hazardous waste and treat waste management as an urgent and essential public service to prevent threats to the environment and the spread of COVID-19 [82].

Acknowledgments The authors are grateful to (Miss. Elyse Yarrick, Miss. Hannah Backman and Miss. Haishat Lolade Idris) for proofreading this manuscript. Special thanks to the anonymous reviewers for their valuable comments to improve the quality of this manuscript.

Funding The authors received no financial support for the research, authorship and /or publication of this manuscript.

Data availability Dataset analyzed during this study is available from the corresponding author upon request.

\section{Compliance with ethical standards}

Conflict of interest The Author(s) declare(s) that there is no conflict of interest.

Human and animal rights This manuscript does not contain any studies with human participants or animal subjects.

\section{References}

1. Afolabi, O. (2017). Liberia: electoral politics in a volatile region. African Journal of Public Affairs, 95-105

2. LISGIS, (2014) Liberia Institute of Statistics and Geo-Information Services (LISGIS) Monrovia, Liberia-Household income and Expenditure survey
3. Akram K et al (2010) Solid waste characterization, quantification and management practices in developing countries. A case study: Nablus district-Palestine. https://doi.org/10.1016/j.jenvm an.2010.01.003

4. Alfaia \& Campos JC (2017) Municipal solid waste in Brazil: A review. Waste Manage Res 35:1195-1209

5. Adedipe NO (2002) The challenge of urban solid waste management in Africa. Umdaus Press, Hatfield, South Africa

6. The World Bank Report (2019) Liberia Government Constraints to Service Delivery- Solid Waste Management- 2019

7. The Statistical Portal (2017) Liberia Urbanization from 2007-2017

8. Dangi and Boland (2017) Assessment of environmental policy implementation in solid waste management in Kathmandu. Nepal Waste Manag Res 35:618-626. https://doi.org/10.1177/07342 42X17699683

9. Szu-Chich \& Chung-Min Liao (2006) Health risk assessment on human exposed to environmental Polycyclic aromatic hydrocarbons pollution sources". Sci Total Environ 366(2006):112

10. Environmental Management Plan Final Report-World Bank, (2003).

11. Dladla FM, Shale K (2016) A review of factors associated with indiscriminate dumping of waste in eleven African countries. African J Sci Technol Innov Develop 8(5-6):475-481. https:// doi.org/10.1080/20421338.2016.1224613

12. Environmental Protection Agency-EPA (2003) An Act Creating the Environmental Protection Agency of Liberia- April 30, 2003

13. Bras AB (2009) Problems and current practices of solid waste management in Port-au-Prince (Haiti). Waste Manag. https:// doi.org/10.1016/j.wasman.2009.07.015

14. Challenges of domestic solid waste management: a case study of Lobatse Botswana (2014) https://doi.org/10.1080/19376 812.2015.1099451

15. David Jr Victor E. John Y, Wenchao J (2019) Solid waste management in Monrovia, Liberia: Implications for sustainable development. J Solid Waste Technol Manag 45(1):102-110(9) 10.5276/JSWTM.2019.102

16. David Jr Victor E. Wenchao J, Mmereki D (2020) Household Solid Waste Management in Liberia: Influencing factors, Characteristics and Management Solutions. J Solid Waste Technol Manag 10.5276/JSWTM/2020.77

17. EMUS (2017) Emergency Monrovia Urban Sanitation Project, Liberia.

18. Eurostat (2013) Waste introduction. https://epp.eurostat. ec.europa.eu/portal/page/portal/waste/introduction

19. Wingqvist ÔG, Slunge S (2013) Governance bottlenecks and policy options for sustainable materials management - A discussion paper. United Nations Development Progamme and the Swedish Environmental Protection Agency. https://www.naturvardsverket.se/Documents/ publikationer6400/978-91-620-8688-6.pdf

20. Wilson DC, Araba AO, Chinwah K, Cheeseman CR (2009) Building recycling rates through the informal sector. Waste Manag 29(2):629-635. https://doi.org/10.1016/j.wasman.2008.06.016

21. Wilson, David \& Velis, Costas \& Rodic-Wiersma, Ljiljana (2013) Integrated sustainable waste management in developing countries

22. UNDP (2006) United Nations Development Programme- State of the Environment (SOE) Report. Monrovia, Liberia: UNDP. Retrieved February 22, 2019 from https://www.thegef.org/sites /default/files/ncsadocuments/State_of_the_environment_repor t_final.pdf

23. United Nations Environment Programme - UNEP (2007) Assessment of Solid Waste Management in Liberia

24. Mmereki D (2018) Current status of waste management in Botswana: A mini-review. Waste Manage Res. https://doi. org/10.1177/0734242X18772097 
25. Besen GR, Fracalanza AP (2016) Challenges for the sustainable management of municipal solid waste in Brazil. Plann Rev 52(45):52

26. Wilson STK et al. (2017) The mining sector of Liberia: Current practices and environmental challenges

27. McAuslan Patrick, (2011) Urban Planning Law of Liberia: The case for a transformational approach.

28. Water and Sanitation Standards in Humanitarian Action (2016) 10.5505/1304.7361.2015.48753

29. Godfrey L, Strydom W. Phukubye R (2016) Integrating the informal sector into the South African waste and recycling economy in the context of Extended Producer Responsibility. CSIR Briefing Note

30. Guerrero LA, Ger Maas G, Hogland W (2013) Solid waste management challenges for cities in developing countries - Review. Waste Manage 33:220-232

31. Joint Monitoring Programme JMP (2017) Progress on drinking water, sanitation and hygiene: 2017 update and SDG baselines, Liberia

32. Gu B, Fujiwara T, Jia R et al (2017) Methodological aspects of modeling household solid waste generation in Japan: Evidence from Okayama and Otsu cities. Waste Manage Res 35:1237-1246

33. Johannessen, L.M. and Boyer, G. (1999). Observations of solid waste landfills in developing countries: Africa, Asia, and Latin America. Urban and Local Government working paper series, No. 19727. Washington, D.C.; The World Bank. https://documents. worldbank.org/curated/ en/393531468741627673/Observationsof-solid-wastelandfills-in-developing-countries-Africa-Asia-andLatin America

34. Liberia Water and Sanitation Sector Portal! https://wash-liber ia.org/

35. David VE et al (2016) Healthcare waste management practices in Liberia: In investigative case study. Int J Waste Res. https://doi. org/10.4172/2252-5211.1000235

36. The Public Health Law, March (1975) Republic of Liberia

37. Kumar S, Bhattacharyya JK, Vaidya AN et al (2009) Assessment of the status of municipal solid waste management in metro cities, state capitals, class I cities, and class II towns in India: An insight. Waste Manage 29:883-895

38. Ministry of Health and Social Welfare-Liberia www.mohsw.gov.lr

39. Environment and Social Management Framework ESMF (2009) liberiamohsw.org/MOH

40. Jerie $S$ (2011) Gender and solid waste management in the informal sector of Bulawayo. Zimbabwe The Dyke 5(1):46-64

41. Abdoli et al (2016) Integrated Solid Waste management in Megacities. https://doi.org/10.7508/gjesm.2016.03.008

42. Mmereki D, Baldwin A, Li B (2016) A comparative analysis of solid waste management in developed, developing and lesser developed countries. Environm Technol Rev. https://doi. org/10.1080/21622515.2016.1259357

43. Rachael E. M. et al. (2013). Systems approaches to integrated solid wastes management in developing countries

44. NSWMP (2011). National Solid Waste Management: Egypt

45. Burton I, Kates R, White G (1993) The environment as hazard. Guilford Press. Retrieved March 22, 2019

46. Ramatta et al (2014) Domestic waste disposal practice and perceptions of private sector waste management in urban Accra

47. Malinauskaite J, Jouhara H, Czajczynska D et al (2017) Municipal solid waste management and waste-to-energy in the context of a circular economy and energy recycling in Europe. Energy 141:2013-2044

48. The role of waste-to-energy in the circular economy (2017) https ://ec.europa.eu/environment/waste/waste-to-energy.pdf

49. de Bercegol R et al (2017) Waste Municipal Service and Informal Recycling Sector in Fast-Growing Asian Cities: Co-Existence, Opposition or Integration? MDPI Resources 6:70
50. The World Bank IBRD (2019) IBRD-IDA Solid Waste Management

51. The World Bank IBRD (2017) -IDA Solid Waste Management

52. The World Bank (2018) IBRD-IDA Solid Waste Management. An updated look into the future of solid waste management www. worldbank.org/en/topic/urbandevelopment/bried/solid-waste -management

53. Udoakah YA (2013) A sustainable approach to municipal solid waste management in southern Nigeria. 2013 IEEE Global Humanitarian Technology Conference (GHTC) (pp. 321-325) IEEE. Retrieved 25 Feb 2019

54. Ranganai RT et al (2004) Geophysical mapping of bedrock structure and leachate plumes at the Gaborone landfill, Botswana

55. Friedrich E, Trois C (2013) Quantification of greenhouse gas emissions from waste management processes for municipalities - A comparative review focusing on Africa. Waste Manage 31:1585-1596

56. Heavy Metals Toxicity and the Environment 10.1007/978-3-7643-8340-4_6

57. United States Environmental Protection Agency (EPA) Progress Cleaning the Air and Improving People's Health https://www. epa.gov/clean-air-act-overview/progress-cleaning-air-and-impro ving-peoples-health

58. David C Wilson, Ljiljana Rodic, Anne Scheinberg, Costas A Velis and Alabaster (2012) Comparative analysis of solid waste management in 20 cities

59. A Review of Landfill Gas Generation and Utilization in Africa (2018) 10.2174/1876325101810010001

60. GIZ (2014) Operator Models. Respecting Diversity: Concepts for Sustainable Waste Management. Deutsche Gesellschaftfür Internationale Zusammenarbeit (GIZ) GmbH, Eschborn (Germany). https://www.giz.de/en/ downloads/giz2013-swm-operator-models-sourcebook-en. Pdf

61. Mpofu TPZ (2013) Urbanization and urban environmental challenges in Sub-Saharan Africa. Res J Agricul Environ Manag 2(6): $127-134$

62. Mukhtar EM, Williams ID, Shaw PJ (2017) Visible and invisible factors of solid waste management in developing countries. 16th International Waste Management and Landfill Symposium, Cagliari, Italy, 2-6 Oct 2017. Sardinia: CISA, pp. 1-9

63. Kayizzi-Mugerwa S, Shimeles A, Yaméogo ND (2014) Urbanization and Socio-economic Development in Africa: Challenges and Opportunities. Routledge African studies series; 16. New York; Routledge

64. Imam et al (2008) Solid Waste Manag Nigeria. https://doi. org/10.1016/j.wasman.2007.01.006

65. Onibokun AG, Kumuyi AJ (1999) Governance and Waste Management in Africa. In: Onibokun AG (Ed) Managing the Monster: Urban Waste Governance in Africa

66. Ma J, Hipel KW (2016) Exploring social dimensions of municipal solid waste management around the globe - A systematic literature review. Waste Manage. https://doi.org/10.1016/j.wasma n.2016.06.041

67. Japan Environmental Sanitation (2012) Center Solid Waste Management and Recycling Technology of Japan-Toward a Sustainable Society https://www.jesco.or.jp/

68. Zohoori M, Ghani A (2017) Municipal Solid Waste Management Challenges and Problems for Cities in Low-Income and Developing Countries

69. Hussein IA, Mansour MSM (2018) Solid waste issue: Sources, composition, disposal, recycling, and valorization

70. McAllister, Jessica, "Factors Influencing Solid-Waste Management in the Developing World" (2015). All Graduate Plan B and other Reports. 528. https://digitalcommons.usu.edu/gradreports/528

71. Urbanization in Liberia $2018 \mathrm{https}: / / \mathrm{www}$.statista.com/statistics /455869/urbanization-in-liberia/ 
72. The role of solid waste management as a response to urban flood risk in developing countries, a case study analysis (2012) 10.2495/FRIAR120161

73. Lamond JN (2012) "The role of solid waste management as a response to urban flood risk in developing countries, a case study analysis.". WIT Transactions on Ecology, 159, 193-204. Retrieved March 2019

74. Kaplan, Zachary A, Kyle, Peter; Shugart, Chris; Moody, Alan (2012) Developing Public-Private Partnerships in Liberia. World Bank. https://openknowledge.worldbank.org/handl e/10986/2244 License: CC BY 3.0 IGO

75. Lino et al (2012) Analysis of the potential of municipal solid waste in Brazil. Environm Develop 4:105-113

76. WASTE, (2017) Integrated Sustainable Waste Management (ISWM) - https://wasteportal.net/en/waste-aspects/integrated -sustainable-waste-management-iswm.

77. A Phased Approach to Project Management Implementation (2010) https://pm-alliance.com/phased-project-management -implementation/.

78. The sustainability of alliances between stakeholders in waste management- Working paper for UWEP/CWG, 30 May $2000 \mathrm{https}: / /$ www.gdrc.org/uem/waste/ISWM.pdf.
79. Miezah K et al (2015) Municipal solid waste characterization and quantification as a measure towards effective waste management in Ghana. https://doi.org/10.1016/j.wasman.2015.09.009

80. Hoornweg D, Bhada-Tata P (2012) What a waste: A Global Review of Solid Waste Management. Urban Development Series Knowledge Papers No. 15. Washington, DC: World Bank. http:// siteresources.worldbank.org/INTURBANDEVELOPMENT/ Resources/336387-1334852610766/What_a_Waste2012_Final. pdf.

81. Bello IA, Ismail MN, Kabbashi NA (2016) Solid Waste Management in Africa: A Review. Int J Waste Res 6(2):1-4. https://doi. org/10.4172/2252-5211.1000216

82. United Nations Environment Program -UNEP (2020) https://www. unenvironment.org/

Publisher's Note Springer Nature remains neutral with regard to jurisdictional claims in published maps and institutional affiliations. 